\title{
Dicranophyllum glabrum (DAWSON) STOPES, AN UNUSUAL ELEMENT OF LOWER WESTPHALIAN FLORAS IN ATLANTIC CANADA
}

\author{
Robert H. WAGNER \\ Centro Paleobotánico, Jardín Botánico de Córdoba, Avda. de Linneo, s/n, \\ 14004 Córdoba (Spain); e-mail: cr1wagro@uco.es
}

\begin{abstract}
Wagner, R. H. 2005. Dicranophyllum glabrum (Dawson) Stopes, an unusual element of lower Westphalian floras in Atlantic Canada. [Dicranophyllum glabrum (Dawson) Stopes, un elemento raro de las floras del Westfaliense inferior del Canadá Atlántico.] Revista Española de Paleontología, 20 (1), 7-13. ISSN 0213-6937.
\end{abstract}

\begin{abstract}
Rare but well preserved repeatedly dichotomised leaves, apparently in a single plane, are identified with Dicranophyllum, an unusual gymnosperm attributed to a special order, the Dicranophyllales. The specimens recorded here from the "Fern Ledges" at Saint John, New Brunswick are from lower Westphalian (Langsettian) strata, which is a low horizon for this genus, which is best known from the Stephanian and Lower Permian. Comparison is made with various species described from the Carboniferous in Europe.
\end{abstract}

Keywords: Dicranophyllum, Langsettian, New Brunswick, Nova Scotia.

\section{RESUMEN}

Se han hallado ejemplares aislados con hojas que se dicotomizan repetidamente en lo que parece ser un solo plano en estratos del Westfaliense inferior (Langsettiense) de los "Fern Ledges" en Saint John, Nueva Brunswick. Estos ejemplares se han atribuido al género Dicranophyllum, una gimnosperma del orden de las Dicranophyllales. Se trata de un registro antiguo para este género, que se conoce sobre todo en materiales del Estefaniense y del Pérmico Inferior. Se compara con varias de las especies descritas del Carbonífero de Europa.

Palabras clave: Dicranophyllum, Langsettiense, New Brunswick, Nueva Escocia.

\section{INTRODUCTION}

In 1871 Sir William Dawson figured a nondescript linear leaf from the "Fern Ledges" locality at Saint John, New Brunswick, under the name of Psilophyton? glabrum (see Fig. 1a under 2). This name was retained by Matthew (1910) for a more complete specimen with repeatedly bifurcate segments (Fig. 1a under 1). A photograph of the latter was published by Stopes (1914) who assigned it to the genus Dicranophyllum Grand'Eury 1877, a rare gymnosperm which was poorly known until Barthel et al. (1998) figured and described remains including seed and pollen bearing organs. However, most species were established on the basis of detached leaves. Dicranophyllum glabrum (Dawson 1871) Stopes 1914 is no exception in this respect.

\section{SYSTEMATIC DESCRIPTION}

ORDER DICRANOPHYLLALES Němejc 1959 emend. Archangelsky \& Cúneo 1990

Family Dicranophyllaceae Němejc 1959 emend. Archangelsky \& Cúneo 1990

The order Dicranophyllales was instituted by Němejc (1959), who distinguished between two families, Trichopityaceae and Dicranophyllaceae, both with a single genus, Trichopitys and Dicranophyllum, which he regarded as ancestral to the Ginkgopsida. Trichopitys had already been considered as an early ginkgophyte by Florin (1951: 296-297), this plant being characterised by shoots with repeatedly bifurcate leaves in the axils of which branching elements with terminal anatropous ovules were placed. 
Archangelsky \& Cúneo (1990) described a similar plant, Polyspermophyllum, with repeatedly bifurcate ovulate branches replacing dichotomously branching leaves on shoots with rhombic leaf cushions, the ovules being also recurved on stalks (anatropous condition). These authors accepted the classification introduced by Němejc (1959) and specified that the two families would differ in the position of the polysperms (female trusses), i.e. an axillary position to vegetative elements (leaves) in the Trichopityaceae, and replacing leaves (borne on leaf-like elements) in the Dicranophyllaceae. The later study of Dicranophyllum hallei Remy \& Remy 1977 by Barthel et al. (1998) and Barthel \& Noll (1999) shows ovuliferous and staminate shoots interspersed with and replacing leaves on the axes with rhombic leaf cushions. However, these ovuliferous shoots (with Samaropsis "seeds") occur as strobili which do not show the repeatedly dichotomous habit of the leaves. Although the basic condition of substitution for leaves is met, Dicranophyllum hallei seems more advanced in its organisation of the fertile elements than Polyspermophyllum.

Archangelsky \& Cúneo (1990) drew attention to the fact that vegetative remains showing merely the repeatedly bifurcate leaves would be difficult to assign beyond the attribution to the order Dicranophyllales. In this respect it is worth drawing attention to the dichotomous branch system or leaf described as Esterella gracilis Boersma \& Visscher 1969, and which was referred to Trichopitys by Remy \& Remy (1977: 129). It is doubtful that the plant remains in question may even be assigned to the Order Dicranophyllales.

\section{Genus Dicranophyllum Grand'Eury 1877}

Diagnosis (mainly deduced from Barthel et al., 1998): Probably rather shallowly rooted bushes with slender aerial axes up to $2 \mathrm{~m}$ tall, unbranched or once bifurcate, showing spirally arranged rhombic leaf cushions with permanently attached, repeatedly dichotomised, simple veined leaves. Seed and pollen bearing organs constituting small strobili occur interspersed with and in substitution of leaves; both female and male strobili being found on the same axes. Winged seeds of Samaropsis aspect.

Remarks: Most species have been distinguished on leaf characters, sometimes on detached leaves, in other cases with known insertion on the axes showing leaf cushions.

Comparisons: The genus Ginkgophyllum Saporta 1875, the type species of which has been refigured by Seward (1919: 87, fig. 669), shows deeply incised leaves, on the dichotomous pattern, but the drawing shows several veins per segment, thus being different from the simple-veined segments of Dicranophyllum leaves. However, later use made of Ginkgophyllum, as summarised by Archangelsky
\& Arrondo (1975), includes Ginkgophyllum diazii Archangelsky \& Arrondo 1975 which shows a bifurcate stem or branch with spirally arranged rhombic leaf cushions with repeatedly dichotomised leaves inserted. These show linear segments with two veins per segment. Length of the leaves is given as being in excess of $10 \mathrm{~cm}$. If it were not for the double vein entering each leaf and servicing the different segments, this species could easily be mistaken for a member of Dicranophyllum. Ginkgophyllum diazii has been refigured by Archangelsky in Archangelsky \& Rocha Campos (1989: pl. 8 figs 1, 1a).

Sphenobaiera Florin 1936 is a wedge-shaped leaf which is deeply segmented. Each segment may contain one to several veins. The abundant documentation by Anderson \& Anderson (1989) shows that the species Sphenobaiera pontifolia Anderson \& Anderson 1989, with repeatedly forked leaves divided into linear leaf segments may be mistaken for Dicranophyllum when cuticle data are not available. Sphenobaiera pontifolia is an Upper Triassic species from South Africa. The genus is not generally susceptible to being confused with Dicranophyllum.

\section{Dicranophyllum glabrum (Dawson 1871) Stopes 1914 \\ Figs 1-2}

1862 Psilophyton? glabrum Dawson, 315 (nomen nudum).

1868 Psilophyton? glabrum Dawson - Dawson, 543 (nomen nudum).

* $1871 \quad$ Psilophyton? glabrum Dawson - Dawson, 41, pl. VII, fig. 79.

? $*$ 1888-90 Dicranophyllum longifolium Renault in Renault \& Zeiller, 631-632, pl. LXXI, fig. 1.

1910 Psilophyton(?) glabrum Dawson - Matthew, 92, pl. VI, figs 1-3.

1914 Dicranophyllum glabrum (Dawson) Stopes, 79-81, pl. XVIII, fig. 47 (same specimen as in Matthew, 1910).

1944 Dicranophyllum glabrum (Dawson) Stopes - Bell, 106, pl. LXXIV, fig. 3.

Material: Two leaves with narrow, ribbon-shaped segments, dichotomously branched up to four times, imprinted on dark grey slaty shales. Provenance: "Fern Ledges" at Saint John, New Brunswick.

Description: Long leaves (the larger specimen measures $23 \mathrm{~cm}$ in length), ribbon-shaped, up to $4 \mathrm{~mm}$ wide near apparent base, forked at a narrow angle at least three times. Leaf endings not preserved. Leaf apparently planated. Leaf lamina flat, with a single, rather wide vein which is strongly marked.

Comparisons: Dicranophyllum glabrum, a lower Westphalian species, is characterised by its long leaves which are forked repeatedly in dichotomous fashion, at a narrow angle. Further details are unknown for this plant which 


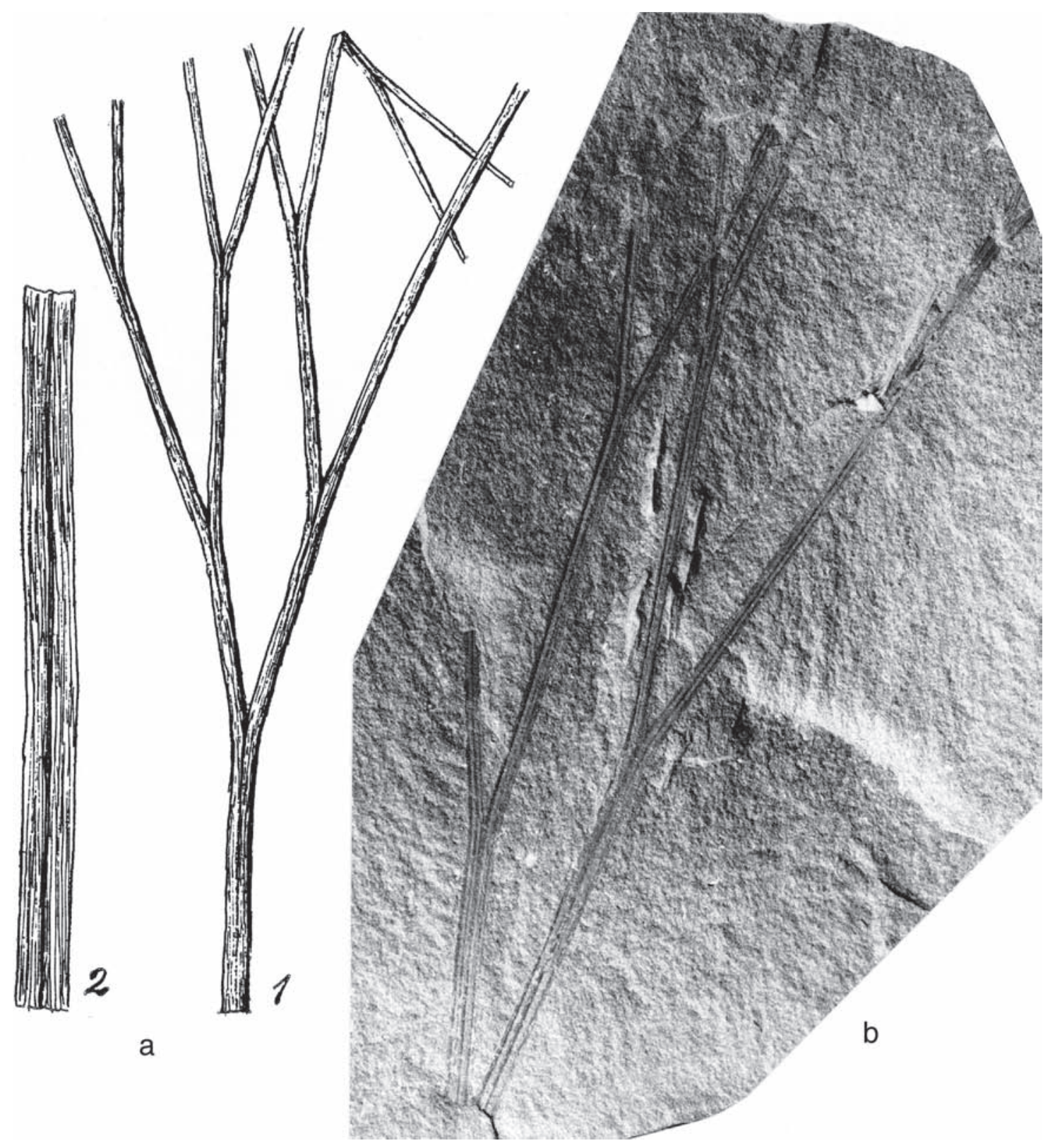

Figure 1. Dicranophyllum glabrum (Dawson 1871) Stopes 1914. a, Copy of Matthew (1910: pl. VI) as Psilophyton? glabrum Dawson; 1, Leaf showing four successive dichotomies; 2, Copy of drawing in Dawson (1871). b, Counterpart of the same specimen (a-1) - NBMG 3513, x 2. Locality: "Fern Ledges" at Saint John, New Brunswick.

lacks evidence of stems and fertile parts. Dicranophyllum longiphyllum Renault (in Renault \& Zeiller 1890), of the Stephanian of Commentry, France, also shows long leaves, dichotomised repeatedly under a narrow angle, and thus presents the same morphological characters. The limited amount of information available for description, and the rather different ages represented, make it inadvisable to join these two very similar species. Dicranophyllum lusitanicum (Heer 1881) Lima 1888, of the upper Stephanian in Portugal, shows long leaves that were apparently forked only once at about two thirds of leaf length (Lima 1888; Wagner \& Sousa; 1983). Another similar species, this time of mid-Namurian age, Dicranophyllum lanceaeformis Josten \& Van Amerom 2003, likewise known only from detached leaves, also shows repeated bifurcations under a narrow angle, but apparently differs in that the basal part of the leaf is robust and displays several bifurcations in quick succession. Josten \& Van Amerom mention the presence of thin, parallel veins in each leaf segment. This does not accord with the usual description of Dicranophyllum leaves which show simple veins marked as a groove in the central part of each leaf segment. A well marked medial vein is not clearly apparent on the photographs published by Josten \& Van Amerom (2003), and if their description of several 

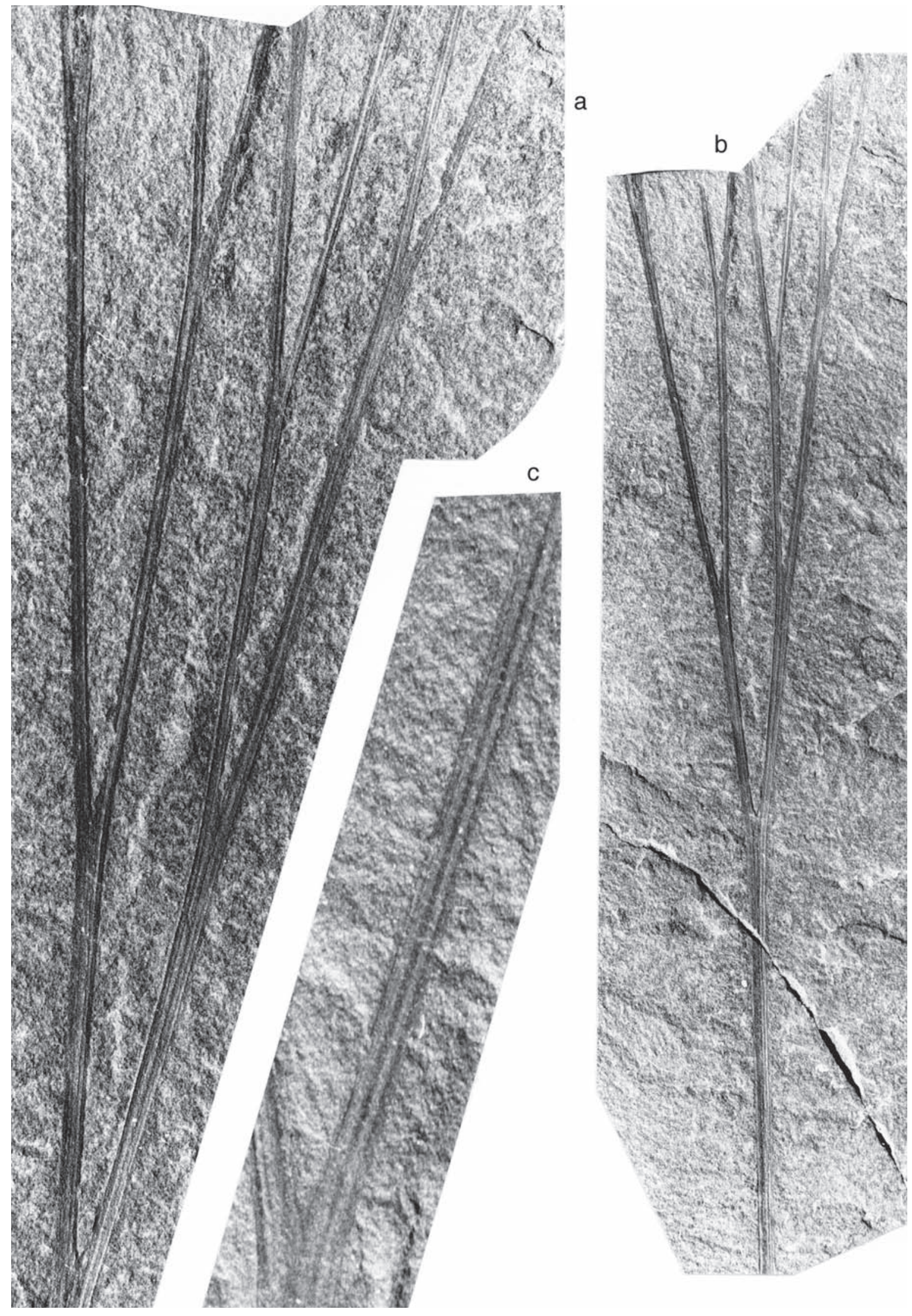

Figure 2. Dicranophyllum glabrum (Dawson 1871) Stopes 1914. a, Large leaf with three successive dichotomies - NBMG 7230, x 2. b, Same specimen x 1. c, Leaf segments of specimen NBMG 3513, x 6, showing simple vein. Locality: "Fern Ledges" at Saint John, New Brunswick. 
parallel veins is correct, there is reason to doubt the attribution to Dicranophyllum. Of course, what may appear to be thin veins, might also be parallel strands of cell tissue which are not necessarily to be interpreted as veins.

The lower Namurian species Dicranophyllum richiri Renier 1907 shows shorter leaves inserted almost perpendicularly on narrow axes with the characteristic rhombic leaf cushions. The well preserved specimens figured by Renier (1907), refigured in part by Renier (in Renier et al., 1910: pl. 117) and Stockmans \& Willière (1952: pl. XV figs 2-4; 1953: 305), display forking near the leaf base at an angle which is not quite as narrow as that for Dicranophyllum glabrum (Dawson 1871) Stopes 1914. Stockmans \& Willière (1952) attribute Renier's locality to "Assise de Chokier", which is of Serpukhovian (late Mississippian) age.

Kidston (1914) described a Dicranophyllum anglicum from the Duckmantian of Staffordshire, England, which shows relatively short leaves with linear leaf segments created by repeated bifurcation under a narrow angle. The single specimen illustrated by Kidston (1914: pl. XIV figs 3, 3a), which was refigured by Crookall (1970: pl. CLV fig. 9), is comparable to both Dicranophyllum glabrum and Dicranophyllum richiri. It is quite possible that Kidston's species is the same as D. glabrum, and that the larger size of the leaves found in the "Fern Ledges" locality corresponds to a different (lower) position on the axes (Kidston's specimen represents a near-terminal position on the branch or small stem). No specific comparisons were made by Crookall beyond the type species of Dicranophyllum, i.e. D. gallicum Grand'Eury 1877.

Dicranophyllum gallicum was first described from the Stephanian of the Saint Étienne Basin in the Massif Central, south-central France (Grand'Eury, 1877; Doubinger et $a l ., 1995)$, and found subsequently in different coalfields in France, Spain, Portugal and Germany, mostly in upper Stephanian and lowermost Permian strata. However, Barthel (1977) includes a single record of this species from the Westphalian D. This is the most commonly recorded species of Dicranophyllum (compare Barthel, 1977). Dicranophyllum gallicum shows stiff leaves inserted on rhombic leaf cushions. A simple vein is in evidence as a marked groove in the centre of a fleshy narrow ribbon-shaped leaf which starts forking dichotomously at some distance from the base and produces one or two additional bifurcations under a narrow angle. This is rather similar to the aspect of the leaves recorded here as Dicranophyllum glabrum, but the size of the leaves in Dawson's species is perhaps a little larger than is normally admitted for Dicranophyllum gallicum. Whether or not this is significant for a specific differentiation, remains an open question. Stopes (1914: 81) emphasised the comparison with $D$. gallicum whilst remarking upon the larger size of the leaves found in Canada. She did not compare with Dicranophyllum longifolium which also shows very long leaves.
H.W.J. van Amerom (pers. comm.) has drawn the author's attention to Esterella gracilis Boersma \& Visscher 1969, a dichotomous branching system which might be a leaf similar to Dicranophyllum glabrum. However, specific identity is excluded because of the wider angle of dichotomous branching, and the apparent lack of a vein (only a longitudinal striation has been noted). Esterella gracilis is incertae sedis.

Remarks: One of the figured specimens (Fig. 1b) is the counterpart of the specimen illustrated by Matthew (1910) and Stopes (1914). This is less complete than the specimen illustrated before, which shows a fourth dichotomy (Fig. 1a, under 1). An additional specimen (Fig. 2) is larger but not very different. Prior to the illustration of the four times bifurcate specimen first recorded by Matthew (1910) with a drawing reproduced here as figure 1-a1, and then figured photographically by Stopes (1914), the species described by Dawson (1871) was known only from a linear leaf fragment without a distinguishing character beyond the strongly marked simple vein (Fig. 1-a2). Matthew (1910) correctly identified his specimen with Dawson's species, but maintained Dawson's tentative generic attribution. Stopes (1914) recognised it as belonging to Dicranophyllum Grand'Eury, a rather poorly known genus at that time. Grand'Eury (1877: 275, pl. XIV figs 8-10) figured axes with lepidodendroid leaf cushions on which repeatedly bifurcate, rather stiff, ribbon-shaped leaves were inserted. The leaves from the "Fern Ledges" locality at Saint John, New Brunswick, are much larger but essentially the same as those figured by Grand'Eury from the Stephanian beds of the Saint Étienne Basin. A second species, Dicranophyllum striatum Grand'Eury 1877, was based entirely on detached leaves which are larger and forked under an even more narrow angle than both Dicranophyllum gallicum and D. glabrum. Although lacking in proof, Grand'Eury (1877: 274) regarded Dicranophyllum as belonging to a new group of conifers, thus ascribing this genus to the gymnosperms. Later work (Renault in Renault \& Zeiller, 1888-90; Barthel et al., 1998) has proved this point of view to be correct. Stopes (1914) mentioned that Dicranophyllum was known to possess "seeds" attached to leaves (as recorded by Renault, 1890), and recognised it as a gymnosperm, but the material from Saint John only consisted of parts of leaves. In a footnote Stopes mentioned that the specimen she illustrated from the collection of the Natural History Society of New Brunswick was not on its own but that a larger specimen existed. This is most likely the additional one figured in the present paper (Fig. 2).

Bell (1944: 106, pl. LXXIV fig. 3) figured as Dicranophyllum glabrum a single fragment of a repeatedly bifurcate leaf from Pudsey Point, Apple River in Cumberland County, Nova Scotia. Although smaller in size, this specimen is probably correctly attributed. However, Dicranophyllum anglicum is an alternative identification. 
Since Dicranophyllum is an extremely rare element of the Carboniferous floras, there has been a tendency to describe the individual finds as different species, hence the relatively large number of species recorded. Since these are based mainly on leaf morphology, which is likely to be variable, it is possible that too many species have been recognised.

The paucity of records suggests that Dicranophyllum may have had ecological requirements different to these prevailing in "coal-measure" associations. This may well have been an extrabasinal element living on better drained soils. It is remarkable to see that the gymnospermous plants attributed to Dicranophyllum ranged in age from late Mississippian to early Permian, and were thus present throughout most of the Carboniferous, although in facies not normally found.

Occurrence: New Brunswick, "Fern Ledges" at Saint John, Langsettian (NBMG 3513, 7230); Nova Scotia, West Beach, Pudsey Point, Apple River, Cumberland County (GSC cat. ${ }^{\circ}$ 3077, locality 1886), Duckmantian.

\section{ACKNOWLEDGEMENTS}

Thanks are due to John Utting and Jean Dougherty of the Geological Survey of Canada for promoting the revision of the upper Namurian and lower Westphalian floras of the Maritime Provinces, including financial support, and for access to the fossil collections in Ottawa. Randall Miller, Curator of Geology at the New Brunswick Museum at Saint John is thanked for access to the collections in his care, and for otherwise promoting the investigation. The New Brunswick Museum is acknowledged for the award of a G.F. Matthew grant-in-aid. The author is grateful for helpful advice by Henk van Amerom.

\section{REFERENCES}

Anderson, J.M. \& Anderson, H.M. 1989. Palaeoflora of southern Africa, Molteno Formation (Triassic). 2. Gymnosperms (excluding Dicroidium). A.A. Balkema, Rotterdam/Brookfield, $567 \mathrm{pp}$.

Archangelsky, S. \& Arrondo, O.G. 1975. Palaeophytologia Kurtziana. III. 11. Dos especies de Ginkgophyllum del Paleozoico Superior de la provincia de La Rioja. Ameghiniana, 11 (año 1974), 357-365.

Archangelsky, S. \& Cúneo, R. 1990. Polyspermophyllum, a New Permian Gymnosperm from Argentina, with considerations about the Dicranophyllales. Review Palaeobotany and Palynology, 63, 117-135.

Archangelsky, S. \& Rocha Campos, A.C. 1985. South America. In: The Carboniferous of the World, II. Australia, Indian Subcontinent, South Africa, South America, \& North Africa (Eds. R.H. Wagner, C.F. Winkler Prins \& L.F. Granados). IUGS Publication $\mathbf{n}^{\mathbf{0}}$ 20. Instituto Geológico y Minero de España \& E.N. Adaro de Investigaciones Mineras. Madrid, 175-297.
Barthel, M. 1977. Die Gattung Dicranophyllum Gr. Eury in den varistischen Innensenken der DDR. Halle'sches Jahrbuch für Geowissenschaften, 2, 73-86.

Barthel, M. \& Noll, R. 1999. On the growth habit of Dicranophyllum hallei Remy et Remy. Veröffentlichungen Naturhistorisches Museum Schleusingen, 14, 59-64.

Barthel, M., Bettag, E. \& Noll, R. 1998. Dicranophyllum hallei Remy \& Remy im oberen Rotliegend. Veröffentlichungen Museum für Naturkunde Chemnitz, 21, 5-20.

Bell, W.A. 1944. Carboniferous rocks and fossil floras of northern Nova Scotia. Canada Department of Mines and Resources, Mines and Geology Branch, Geological Survey, Memoir 238, 119 pp.

Boersma, M. \& Visscher, H. 1969. On two Late Permian Plants from southern France. Mededelingen Rijks Geologische Dienst, (N.S.), 20, 57-63.

Crookall, R. 1970. Fossil Plants of the Carboniferous Rocks of Great Britain (Second Section). Memoirs Geological Survey of Great Britain. Palaeontology, IV (6), 793-838.

Dawson, J.W. 1862. On the Flora of the Devonian Period in North-Eastern America. Quarterly Journal Geological Society of London, XVIII, 296-330.

Dawson, J.W. 1868. Acadian Geology. The Geological Structure, Organic Remains, and Mineral Resources of Nova Scotia, New Brunswick, and Prince Edward Island. $\left(2^{\text {nd }}\right.$ edition), London, $694 \mathrm{pp}$.

Dawson, J.W. 1871. The Fossil Plants of the Devonian and Upper Silurian Formations. Geological Survey of Canada, Report, 92 pp.

Doubinger, J., Vetter, P., Langiaux, J., Galtier, J. \& Broutin, J. 1995. La flore fossile du bassin houiller de Saint-Étienne. Mémoires Muséum National d'Histoire naturelle, 164. Paléobotanique, 355 pp.

Florin, R. 1936. Die fossilen Ginkgophyten von Franz-JosephLand, nebst Erörterungen über vermeintliche Cordaitales mesozoischen Alters. 2. Algemeiner Teil. Palaeontographica $B, 82,1-72$.

Florin, R. 1951. Evolution in cordaites and conifers. Acta Horti Bergiani, 15 (11), 285-388.

Grand'Eury, F.C. 1877. Mémoire sur la flore carbonifère du département de la Loire et du centre de la France, étudiée aux trois points de vue botanique, stratigraphique et géognostique. Mémoires Académie des Sciences, Institut National de France, XXIV, 624 pp.

Heer, O. 1881. Contributions à la flore fossile du Portugal. Section des Travaux Géologiques du Portugal. Lisbonne.

Josten, K.-H. \& Amerom, H.W.J. van 2003. Die Flora des Namur B aus Hagen-Vorhalle. Geologie und Paläontologie in Westfalen, 61, $312 \mathrm{pp}$.

Kidston, R. 1914. On the Fossil Flora of the Staffordshire Coal Fields. Part III.- The Fossil Flora of the Westphalian Series of the South Staffordshire Coal Field. Transactions Royal Society of Edinburgh, L, pt I (5), 73-190.

Lima, W. de 1888. Flora fossil de Portugal (Flore fossile du Portugal). Monographia do genero Dicranophyllum (Systema Carbonico). (Monographie du Genre Dicranophyllum Grand'Eury (Système Carbonique)). Comissão dos Trabalhos Geologicos de Portugal, Lisboa, 35 pp. 
Matthew, G.F. 1910. Revision of the Flora of the Little River Group No II. Transactions Royal Society of Canada, Section $I V$, ser. 3, 3, 77-109.

Němejc, F. 1959. Notes on the evolution and taxonomy of the stachyospermic gymnosperms. Preslia, 31, 251-272.

Remy, W. \& Remy, R. 1977. Die Floren des Erdaltertums. Einführung in Morphologie, Anatomie, Geobotanik und Biostratigraphie der Pflanzen des Paläophytikums. Verlag Glückauf/GMBH, Essen, 468 pp.

Renault, B. \& Zeiller, R. 1888-90. Études sur le Terrain houiller de Commentry. 2. Flore fossile. Société de 1'Industrie minérale, $3^{\mathrm{e}}$ série, II (2), 746 pp. (Texte), pls I-LXXV (Atlas).

Renier, A. 1907. Trois espèces nouvelles Sphenopteris Dumonti, Sphenopteris Corneti et Dicranophyllum Richiri du houiller sans houille de Baudour, Hainaut. Annales Société géologique de Belgique, XXXIV, 181-196.

Renier, A., Cambier, R., Deltenre, H. \& Schmitz, G. 1910. Documents pour l'étude de la Paléontologie du Terrain houiller. Imprimerie H. Vaillant-Carmanne, Liège, 26 pp., pls 1-118 (Atlas).

Saporta, G. 1875. Sur la découverte de deux types nouveaux de conifères dans les schistes permiens de Lodève (Herault). Comptes rendus de l'Académie des Sciences, Paris, 80, 1017-1022.

Seward, A.C. 1919. Fossil Plants. A text-book for students of Botany and Geology. vol. IV. Ginkgoales, Coniferales, Gnetales. Cambridge University Press, 543 pp.

Stockmans, F. \& Willière, Y. 1952-53. Végétaux namuriens de la Belgique. Association pour l'Étude de la Paléontologie et de la Stratigraphie Houillères, Publication 13, 382 pp. (1953), 57 pls (1952).

Stopes, M.C. 1914. The "Fern Ledges" Carboniferous Flora of St. John, New Brunswick. Geological Survey of Canada, Memoir 41 (38 of Geological Series), 142 pp.

Wagner, R.H. \& Sousa, J.M.L. 1983. The Carboniferous megafloras of Portugal-Arevision of identifications and discussion of stratigraphic ages. In: The Carboniferous of Portugal. (Eds. M.J. Lemos de Sousa \& J.T. Oliveira). Memórias dos Serviços Geológicos de Portugal, 29, 127-152.

Manuscrito recibido: 24 de Mayo, 2004 Manuscrito aceptado: 13 de Diciembre, 2004 